\title{
An Experimental Study on Biosorption of Fluoride from Water Using Locally Obtained Moringa Oleifera Seeds
}

\author{
Faheem Akhter ${ }^{1,}{ }^{*}$, Arsalan Aziz Jokhio ${ }^{2}$, Javed Ahmed Noonari ${ }^{2}$ \\ ${ }^{1}$ Department of Chemical Engineering, QUEST, Nawabshah, Pakistan. \\ ${ }^{2}$ Department of Chemical Engineering, MUET, Jamshoro, Pakistan. \\ ${ }^{*}$ Corresponding author: faheemakhtar86@quest.edu.pk
}

Abstract

Moringa Oleifera is considered to be a natural bio-adsorbent. Unlike chemical coagulants, Moringa Oleifera seeds are environment friendly with various other advantages. The present study investigated the fluoride removal efficiency of Moringa Oleifera from water. Influence of adsorbent dose (1, 2, $4 \mathrm{~g} / \mathrm{L})$, contact time (20, 40 and $60 \mathrm{~min})$ and initial fluoride concentration ( 2 and $5 \mathrm{mg} / \mathrm{L}$ ) over removal efficiency were determined and optimized. It was found that increased adsorbent dose and contact time enhanced the removal efficiency which is in agreement with the previous studies. The highest removal of $88.1 \%$ was achieved when the adsorbent dose and contact time were optimized to 4 $\mathrm{g} / \mathrm{L}$ and 60 minutes with an initial fluoride concentration of $2 \mathrm{mg} / \mathrm{L}$. The results showed that Moringa Oleifera can be used as an environment friendly, cheap and effective bio-adsorbent for fluoride removal from aqueous solution. All the experimental facilities were provided by Bio-Fuel Lab, Energy \& Environment Department, Quaid-e-Awam University of Engineering, Science and Technology, Nawabshah, Pakistan. The samples were analyzed at the Pakistan Council of Research in Water Resources (PCRWR), Tando Jam, Pakistan.

Keywords-Moringa Oleifera, bio-adsorbent, fluoride, aqueous solution

\section{Introduction}

$\mathrm{F}$ LUORIDES are significant modern industrial chemicals with various uses, however, the excess limit of such chemicals in water is hazardous [1-2]. The admissible limit set by the World health organization (WHO) is $1-1.5 \mathrm{mg} / 1$ [3]. Consuming fluoride in excess can lead to many diseases including cancer, teeth damaging, respiratory problems, reduce pregnancy, softening of bones and damage to the kidney-livernervous system [1]. It is obvious that there are various alternate strategies available, but such conventional techniques either involve a high cost, low removal capacity, undesirable effects, generate excessive sludge or complex treatment procedures [3-4]. Additionally, most of the de-fluoridation techniques are neither proven nor trustworthy under field condition in developing agricultural nations. Considering the genuine disadvantages, there is an extraordinary demand to build up an active, viable and environmental friendly

ISSN: 2523-0379 (Online), ISSN: 1605-8607 (Print)

DOI: https://doi.org/10.52584/QRJ.1901.05

This is an open access article published by Quaid-e-Awam University of Engineering Science \& Technology, Nawabshah, Pakistan under CC BY 4.0 International License. adsorbent for the expulsion of fluoride from drinking water [4-5]. To this end, a large number of different adsorbents like macrophytes such as Eich horniacrassipes, fungi, algae and yeast have been explored as bio adsorbents [6]. In the present study, the seeds of Moringa Oleifera were used as bio-adsorbent to eliminate fluoride particles from water. Earlier studies have suggested Moringa Oleifera to be non-harmful and can be used as a bio-adsorbent [3][4][7][8]. Due to its biological properties, Moringa Oleifera has a viable and environmental friendly advantage over chemical treatment. It has been demonstrated to be a primary coagulant and compared with alum [3-5][9][10].

Pakistan is among those nations who are facing clean drinking water issues. About 21.6 million inhabitants in Pakistan have no admittance to clean drinking water [11]. Nangarparkar is a region lying in Tharparkar region of Sindh where the groundwater sources contain excess amounts of fluoride [12]. The fluoride concentration in the groundwater of this region can range up to 7.85 with the mean value of 3.33 $\mathrm{mg} / \mathrm{L}$, which is far from the permissible range of WHO [13]. During the present study, the Moringa Oleifera 
seeds were collected locally from the areas Khairpur and Shikarpur. These areas are abundant in Moringa Oleifera tress and not too far from Nangarparkar. Hence, the locally collected Moringa Oleifera seeds can be utilized to reduce the excess fluoride concentration from the drinking water of Nangarparkar, Sindh, Pakistan.

\section{Materials \& Methods}

All the experiments were performed under ambient pressure/temperature conditions. All the chemicals were of laboratory grade. Following sections provide the details of the materials and methods used in this study.

\subsection{Collection and Preparation of Moringa Oleifera (Bio-adsorbent)}

The Moringa Oleifera seeds were collected locally from two cities of Pakistan: Khairpur and Shikarpur. The seeds were de-shelled and washed with distilled water to remove the adhering dirt and impurities followed by oven drying (ISUZU 2-2050) at $110{ }^{\circ} \mathrm{C}$ for 72 hours. The dried seeds were ground and sieved through $1 \mathrm{~mm}$ mesh. The sieved powder of Moringa Oleifera was stored in zip-lock polyethylene bags until further use.

\subsection{Preparation of Fluoride Solution}

The fluoride solution was prepared by the method described in [14]. The sodium fluoride was dried to a constant weight in a drying oven at $105^{\circ} \mathrm{C}$ followed by storing in a desiccator. 2.21 grams of anhydrous sodium fluoride was vigorously mixed in one liter of distilled water. This stock solution was used to prepare 2 diluted solutions with $2 \mathrm{mg} / \mathrm{L}$ and $5 \mathrm{mg} / \mathrm{L}$ concentrations. For making $2 \mathrm{mg} / \mathrm{L}$ diluted solution, 2 $\mathrm{mL}$ was taken from the stock solution via pipette and poured in 1 liter distilled water. Fresh dilutions were prepared for each experiment.

\subsection{Loading Fluoride Solutions with Bio- adsorbent Dose}

During the present study, 2 parameters were analyzed to see the adsorption capacity, namely bio-adsorbent dose and contact time. The capacity was investigated by loading the already prepared fluoride solutions with varying bio-adsorbent doses. Loaded mixture samples were placed on a magnetic stirrer at $60 \mathrm{rpm}$ and stirred for different contact time segments. After stirring, the mixture samples were allowed to settle and filtered with Whatman 41 filter paper. The filtrate was collected in sampling bottles and analyzed for fluoride

\begin{tabular}{|l|l|l|l|}
\hline \multicolumn{4}{|c|}{$\mathbf{2 m g} /$ L initial fluoride concentration } \\
\hline $\begin{array}{l}\text { Adsorbent } \\
\text { dose }\end{array}$ & $\begin{array}{l}\text { Fluoride } \\
\text { retained } \\
\text { in a solution } \\
(\mathbf{m g})\end{array}$ & $\begin{array}{l}\text { Fluoride } \\
\text { removed } \\
(\mathbf{m g})\end{array}$ & \% removed \\
\hline $1 \mathrm{~g}$ & 1.26 & 0.74 & $36.8 \%$ \\
\hline $2 \mathrm{~g}$ & 0.64 & 1.36 & $68.2 \%$ \\
\hline $4 \mathrm{~g}$ & 0.24 & 1.76 & $88.1 \%$ \\
\hline
\end{tabular}

TABLE 1: Impact of adsorbent dose on fluoride percentage removal efficiency at $2 \mathrm{mg} / \mathrm{l}$ initial fluoride concentration

removal at Pakistan Council of Research in Water Resources (PCRWR), Tando Jam, Pakistan. The fluoride removal from the filtrate samples was analyzed using Colorimeter DR/890. The removal efficiency (\%) was calculated using the following formula:

Removal efficiency ( $\%)=C_{0}-C_{e} / C_{0} C_{0}$ initial fluoride concentration in solution $C_{e}$ final fluoride concentration in solution

\section{Results \& Discussion}

The following sections present the results of this study.

\subsection{Effect of Bio-Adsorbent Dose on Fluoride Removal}

The prepared fluoride solutions with the initial concentration of $2 \mathrm{mg} / \mathrm{L}$ and $5 \mathrm{mg} / \mathrm{L}$ were loaded with $1 \mathrm{~g}, 2 \mathrm{~g}$ and $4 \mathrm{~g}$ of bio-adsorbent doses (Table 1-2). The removal percentage by the bio-adsorbent was determined. Figure 1 shows the 3 fluoride solutions with an initial fluoride concentration of $2 \mathrm{mg} / \mathrm{L}$ loaded with $1 \mathrm{~g}, 2 \mathrm{~g}$ and $4 \mathrm{~g}$ of bio-adsorbent dosage. The highest removal percentage was achieved with $4 \mathrm{~g}$ of dosage. Similarly, Figure 2 shows the fluoride solutions with an initial concentration of $5 \mathrm{mg} / \mathrm{L}$ loaded with $1 \mathrm{~g}, 2 \mathrm{~g}$ and $4 \mathrm{~g}$ of adsorbent dosage. The highest removal percentage achieved at $4 \mathrm{~g}$ dosage. It was found that increased adsorbent dose increases the removal percentage. Furthermore, at $2 \mathrm{mg} / \mathrm{L}$ initial fluoride concentration, when the adsorbent dose is increased from $1 \mathrm{~g}$ to $2 \mathrm{~g}$, removal efficiency is improved by $31.4 \%$, whereas only $19.9 \%$ enhanced removal efficiency is observed when the adsorbent dose is raised from $2 \mathrm{~g}$ to $4 \mathrm{~g}$. Similarly, at $5 \mathrm{mg} / \mathrm{L}$ initial fluoride concentration, the removal efficiency improved by $24.8 \%$ from $1 \mathrm{~g}$ to $2 \mathrm{~g}$, whereas only 19.05\% improvement was observed from $2 \mathrm{~g}$ to $4 \mathrm{~g}$. In both the cases, $4 \mathrm{~g}$ of adsorbent dose enhanced the mean removal percentage by $47.5 \%$ in comparison with $1 \mathrm{~g}$. Moreover, in both the cases, a higher improved removal percentage was observed between $1 \mathrm{~g}$ and $2 \mathrm{~g}$ of adsorbent doses. 


\begin{tabular}{|l|l|l|l|}
\hline \multicolumn{4}{|c|}{$\mathbf{m g} /$ L initial fluoride concentration } \\
\hline $\begin{array}{l}\text { Adsorbent } \\
\text { dose }\end{array}$ & $\begin{array}{l}\text { Fluoride } \\
\text { retained } \\
\text { in a solution } \\
(\mathbf{m g})\end{array}$ & $\begin{array}{l}\text { Fluoride } \\
\text { removed } \\
\mathbf{( m g )}\end{array}$ & \% removed \\
\hline $1 \mathrm{~g}$ & 3.35 & 1.65 & $33.4 \%$ \\
\hline $2 \mathrm{~g}$ & 2.1 & 2.9 & $58.2 \%$ \\
\hline $4 \mathrm{~g}$ & 1.15 & 3.85 & $77.25 \%$ \\
\hline
\end{tabular}

TABLE 2: Impact of adsorbent dose on fluoride percentage removal efficiency at $5 \mathrm{mg} / \mathrm{l}$ initial fluoride concentration

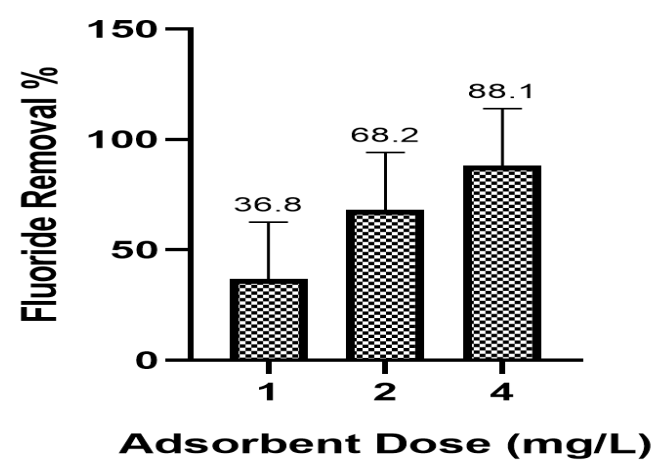

Fig. 1: Bio-adsorbent dose in $2 \mathrm{mg} / \mathrm{L}$ fluoride solution

\subsection{Effect of Contact Time on Fluoride Removal}

The effect of contact time was investigated by loading the fluoride samples with varying bio-adsorbent doses and contact time, as shown in the Figure 3-4. The highest removal percentage of $88.1 \%$ was achieved when the solution was loaded with $4 \mathrm{~g} / \mathrm{L}$ of bio-adsorbent dose for 60 minutes of contact time and initial fluoride concentration of $2 \mathrm{mg} / \mathrm{L}$, respectively (Figure 3). Similarly, with initial fluoride concentration of $5 \mathrm{mg} / \mathrm{L}$, the highest removal of $77.25 \%$ was observed at the bio-adsorbent dose of $4 \mathrm{~g} / \mathrm{L}$ with a contact time of 60 minutes. It was found that the increased contact time

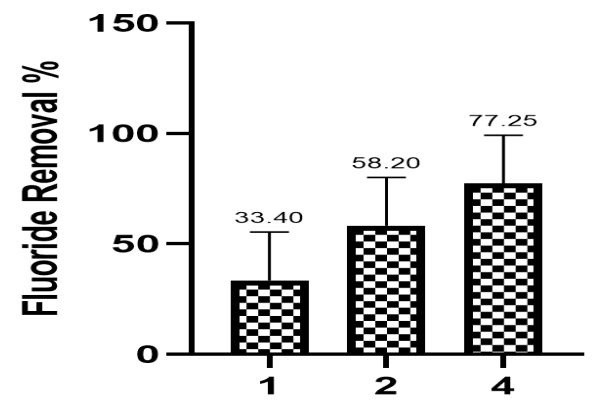

Adsorbent Dose (mg/L)

Fig. 2: Bio-adsorbent dose in $5 \mathrm{mg} / \mathrm{L}$ fluoride solution

\begin{tabular}{|l|l|l|l|}
\hline \multicolumn{4}{|c|}{ At 2mg/L initial fluoride concentration } \\
\hline \multirow{2}{*}{$\begin{array}{l}\text { Adsorbent } \\
\text { dose }\end{array}$} & $\begin{array}{l}\text { Contact } \\
\text { time } \\
\text { (min) }\end{array}$ & $\begin{array}{l}\text { Fluoride } \\
\text { removed } \\
\text { (mg) }\end{array}$ & \% removed \\
\hline \multirow{3}{*}{$1 \mathrm{~g} / \mathrm{L}$} & 20 & 0.045 & $9.0 \%$ \\
\cline { 2 - 4 } & 40 & 0.44 & $22.2 \%$ \\
\cline { 2 - 4 } & 60 & 0.74 & $36.82 \%$ \\
\hline \multirow{3}{*}{$2 \mathrm{~g} / \mathrm{L}$} & 20 & 0.38 & $19.2 \%$ \\
\cline { 2 - 4 } & 40 & 0.86 & $43.02 \%$ \\
\cline { 2 - 4 } & 60 & 1.36 & $68.2 \%$ \\
\hline \multirow{3}{*}{$4 \mathrm{~g} / \mathrm{L}$} & 20 & 0.72 & $36.37 \%$ \\
\cline { 2 - 4 } & 40 & 1.24 & $61.95 \%$ \\
\cline { 2 - 4 } & 60 & 1.76 & $88.1 \%$ \\
\hline
\end{tabular}

TABLE 3: Impact of contact time on fluoride percentage removal efficiency at different adsorbent dose at $2 \mathrm{mg} / \mathrm{L}$ initial fluoride concentration
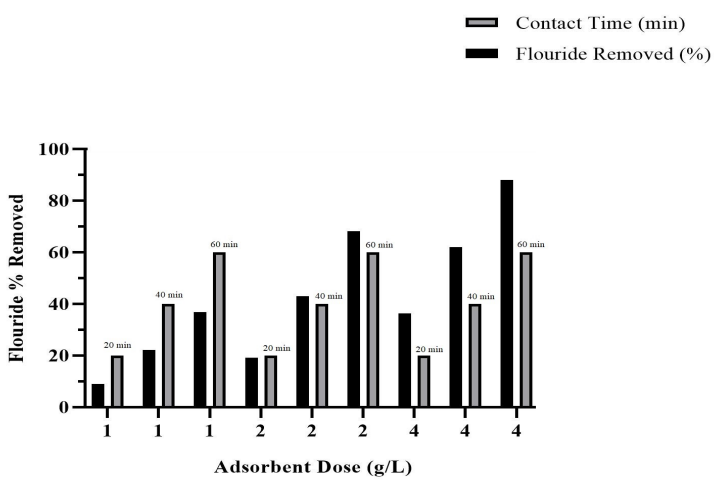

Fig. 3: Impact of contact time on fluoride percentage removal efficiency at different adsorbent dose at $2 \mathrm{mg} / \mathrm{L}$ initial fluoride concentration

improved the fluoride removal percentage.

The results of the present study show a remarkable efficacy of the locally obtained Moringa Oleifera for fluoride removal when compared with the earlier research. For example, the authors in [15] reported

\begin{tabular}{|l|l|l|l|}
\hline \multicolumn{4}{|c|}{ At 5mg/L initial fluoride concentration } \\
\hline \multirow{2}{*}{$\begin{array}{l}\text { Adsorbent } \\
\text { dose }\end{array}$} & $\begin{array}{l}\text { Contact } \\
\text { time } \\
\text { (min) }\end{array}$ & $\begin{array}{l}\text { Fluoride } \\
\text { removed } \\
\text { (mg) }\end{array}$ & \% removed \\
\hline \multirow{3}{*}{$1 \mathrm{~g} / \mathrm{L}$} & 20 & 0.3 & $6.14 \%$ \\
\cline { 2 - 4 } & 40 & 0.85 & $17.2 \%$ \\
\cline { 2 - 4 } & 60 & 1.65 & $33.4 \%$ \\
\hline \multirow{3}{*}{$2 \mathrm{~g} / \mathrm{L}$} & 20 & 0.7 & $13.89 \%$ \\
\hline \multirow{3}{*}{$4 \mathrm{~g} / \mathrm{L}$} & 40 & 1.45 & $29.12 \%$ \\
\cline { 2 - 4 } & 60 & 2.9 & $58.2 \%$ \\
\cline { 2 - 4 } & 20 & 1.6 & $32.2 \%$ \\
\cline { 2 - 4 } & 40 & 2.25 & $45.21 \%$ \\
\cline { 2 - 4 } & 60 & 3.85 & $77.25 \%$ \\
\hline \multirow{2}{*}{} & & \multicolumn{2}{|c}{} \\
\hline
\end{tabular}

TABLE 4: Impact of contact time on fluoride percentage removal efficiency at a different adsorbent dose at $5 \mathrm{mg} / \mathrm{L}$ initial fluoride concentration 
Contact Time (min)

- Flouride Removed (\%)

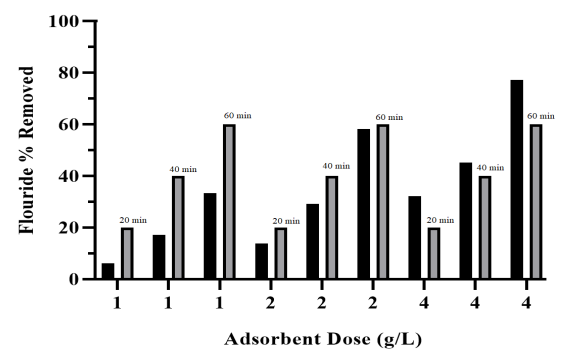

Fig. 4: Impact of contact time on fluoride percentage removal efficiency at a different adsorbent dose at $5 \mathrm{mg} / \mathrm{L}$ initial fluoride concentration

to obtain $83 \%$ percent of fluoride removal at $5 \mathrm{mg} / \mathrm{L}$ of initial fluoride concentration, where as the present study was able to achieve the highest of $77.25 \%$ under the same conditions. Another study [16] was able to achieve the highest fluoride removal of $79.85 \%$ at $2 \mathrm{mg} / \mathrm{L}$ of initial fluoride concentration, while the present study comparatively achieved higher removal percentage of $88.1 \%$ under identical conditions which shows the competitive efficiency of locally obtained Moringa Oleifera. Furthermore, the increased levels of MO dosage and initial fluoride concentration resulted in higher fluoride removal which is in agreement with the previous studies [4][5][8][17][18].

\section{Conclusion}

In this study, the fluoride removal efficiency of bioadsorbent (Moringa Oleifera) was investigated. Two parameters were analyzed and optimized, namely bioadsorbent dose and contact time. During adsorption dose investigation, the highest removal of $88.1 \%$ was achieved when fluoride solution with a concentration of $2 \mathrm{mg} / \mathrm{L}$ was loaded with $4 \mathrm{~g} / \mathrm{L}$ dose. Similarly, at $5 \mathrm{mg} / \mathrm{L}$ initial fluoride solution, the adsorbent dose of $4 \mathrm{~g} / \mathrm{L}$ achieved the highest removal of $77.25 \%$. Furthermore, the contact time was shown to have a significant impact on fluoride removal percentage. The highest removal of $88.1 \%$ was achieved with a contact time of 60 minutes. The present study shows that Moringa Oleifera has a good potential as a bioadsorbent for removing fluoride from water. The bioadsorbent is environment-friendly and can be used as a replacement of various chemical coagulants. Pertaining to the mentioned region with a mean fluoride value of $3.33 \mathrm{mg} / \mathrm{L}$ in groundwater, the method proposed in this method can bring that value down to $0.39 \mathrm{mg} / \mathrm{L}$ (2mg/L initial fluoride conc. and $4 \mathrm{~g}$ adsorbent dose) and $0.75 \mathrm{mg} / \mathrm{L}(5 \mathrm{mg} / \mathrm{L}$ initial fluoride conc. and $4 \mathrm{~g}$ adsorbent dose) which is within WHO's permissible limits. Hence, the study highly recommends the use of locally collected Moringa Oleifera seeds to remove fluoride from the drinking water of Nangarparkar region, Sindh, Pakistan.

\section{Acknowledgement}

The authors wish to thank Bio-Fuel Lab, Energy and Environment Department, Quaid-e-Awam University of Engineering, Science \& Technology, Nawabshah, Pakistan for the provision of facilities and support.

\section{References}

[1] B. Laney, O. M. Rodriguez-Narvaez, B. Apambire, and E. R. Bandala, "Water Defluoridation Using Sequentially Coupled Moringa oleifera Seed Extract and Electrocoagulation," Groundw. Monit. Remediat., vol. 40, no. 3, pp. 67-74, 2020.

[2] P. Dhama, "Comparison of Fluoride Uptake between Moringa Oleifera and Tamarindus Indica," International Journal of Innovations in Engineering Research and Technol-ogy, Vol. 8, No. 2, pp. 33-40, 2021.

[3] V. L. Chee, C. H. Chong, C. M. Choo, and T. S. Y. Choong, "Combined natural and chemical coagulants to remove fluoride from wastewater," IOP Conf. Ser. Mater. Sci. Eng., Vol. 778 , No. 1, 2020.

[4] N. Ueda Yamaguchi et al., "A review of Moringa oleifera seeds in water treatment: Trends and future challenges," Process Saf. Environ. Prot., Vol. 147, pp. 405-420, 2021.

[5] B. M. Tiimub, J. J. Agyenta, R. Osei-Bonsu, A. E. Azure, G. L. Tiimob, and O.-B. Rama, "Asante Mampong, Ghana 3 Higher Level Teacher Education Expert, N.I.B. School, GES, Techiman, B.E. Region 4 Specialist at Supervisory Section (Public Health \& Nutrition)," Chem. Res. J. 58 Train. Entrep. Dev., Vol. 6, No. 2, pp. 58-71, 2021.

[6] R. M. Hegde, R. M. Rego, K. M. Potla, M. D. Kurkuri, and M. Kigga, "Bio-inspired materials for defluoridation of water: A review," Chemosphere, Vol. 253, 2020.

[7] G. Aboagye, M. Navele, and E. Essuman, "Protocols for assessing antibacterial and water coagulation potential of Moringa oleifera seed powder," MethodsX, Vol. 8, p. $101283,2021$.

[8] D. Chitra and L. Muruganandam, "Performance of Natural Coagulants on Greywater Treatment," Recent Innov. Chem. Eng. (Formerly Recent Patents Chem. Eng., Vol. 13, No. 1, pp. 81-92, 2019.

[9] J. Beltrán-Heredia, J. Sánchez-Martín, and M. A. DávilaAcedo, "Optimization of the synthesis of a new coagulant from a tannin extract," J. Hazard. Mater., Vol. 186, No. 2-3, pp. 1704-1712, 2011.

[10] A. S. Taiwo, K. Adenike, and O. Aderonke, "Efficacy of a natural coagulant protein from Moringa oleifera (Lam) seeds in treatment of Opa reservoir water, Ile-Ife, Nigeria," Heli-yon, Vol. 6, No. 1, 2020.

[11] J. Ahmed, L. P. Wong, Y. P. Chua, and N. Channa, "Drink-ing water quality mapping using water quality index and geospatial analysis in primary schools of pakistan," Water (Switzerland), Vol. 12, No. 12, 2020.

[12] N. Masood, S. Batool, and A. Farooqi, "Groundwater pollu-tion in Pakistan," Glob. Groundw., pp. 309-322, 2021. 


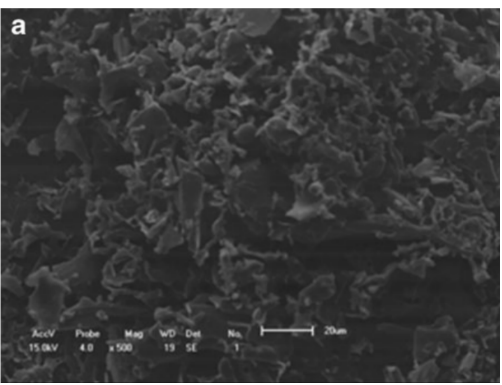

(a) Filtered Moringa Oleifera seeds

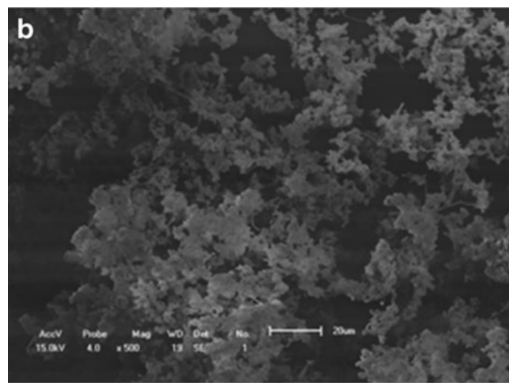

(b) Water with excess fluoride

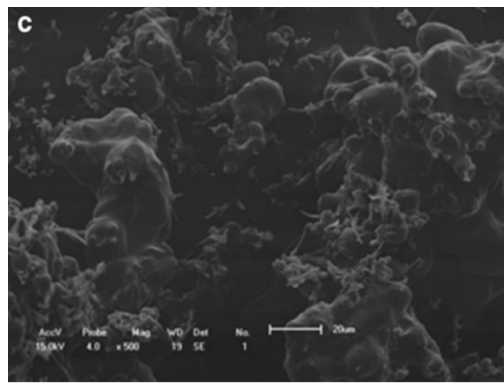

(c) Water after fluoride removal

Fig. 5: SEM images of the samples

[13] S. Naseem, T. Rafique, E. Bashir, M. I. Bhanger, A. Laghari, and T. H. Usmani, "Lithological influences on occurrence of high-fluoride groundwater in Nagar Parkar area, Thar De-sert, Pakistan," Chemosphere, Vol. 78, No. 11, pp. 1313-1321, 2010.

[14] T. M. Seid, "Biosorption of fluoride ion from water using the seeds of the cabbage tree (Moringa stenopetala)," African J. Environ. Sci. Technol., Vol. 11, No. 1, pp. 1-10, 2017.

[15] Vardhan, CM Vivek, and J. Karthikeyan. "Removal of fluoride from water using low-cost materials." In Fifteenth International Water Technology Conference, IWTC-15, pp. 1-14. 2011.

[16] Jafari, Ali, Amir Hossein Mahvi, Hatam Godini, Reza Rezaee, and Sara Sadat Hosseini. "Process optimization for fluoride removal from water by Moringa oleifera seed extract." Fluoride, Vol. 7, No. 2, pp. 152-60, 2014.

[17] C. Y. Yin, "Emerging usage of plant-based coagulants for water and wastewater treatment," Process Biochemistry, Vol. 45, No. 9. Elsevier, pp. 1437-1444, 2010.

[18] R. Sowmeyan, J. Santhosh, and R. Latha, "Effectiveness of herbs in community water treatment," Int. Res. J. Biochem. Bioinforma. Vol. 1, No. 11, pp. 297-303, 2011. 